JEKPEND Jurnal Ekonomi dan Pendidikan

Volume 2 Nomor 1 Januari 2019. Hal. 15-20

p-ISSN: 2614-2139; e-ISSN: 2614-1973,

Homepage:http://ojs.unm.ac.id/JEKPEND

\title{
PENERAPAN MODEL PEMBELAJARAN KOOPERATIF TIPE STAD DALAM MENINGKATKAN HASIL BELAJAR EKONOMI DI KELAS XI SMA NEGERI 10 BULUKUMBA
}

\author{
Nelly \\ Guru Mata Pelajaran Ekonomi SMA Negeri 10 Bulukumba \\ Email: nellycawank@gmail.com
}

\begin{abstract}
This study aims to determine the economic learning outcomes of students by using the STAD Cooperative Learning Model (Student Teams Achievement Division). The method used is a classroom action research approach that takes place in two cycles. Data are analyzed quantitatively and qualitatively. The results of the study showed that the learning outcomes of students in the material analyzing employment problems in Indonesia experienced an increase. This is based on the results of the analysis carried out, obtained classical completeness that is 53.33 percent increased to 86.67 percent.
\end{abstract}

Keywords: Cooperative Learning; STAD; Classroom action research

\begin{abstract}
Abstrak. Penelitian ini bertujuan untuk mengetahui hasil belajar ekonomi siswa dengan menggunakan Model Pembelajaran Kooperatif tipe STAD (Student Teams Achievement Division). Metode yang digunakan yaitu pendekatan penelitian tindakan kelas yang berlangsung dalam dua siklus. Data dianalisis secara kuantitatif dan kualitatif.

Hasil penelitian menunjukkan bahwa hasil belajar peserta didik pada materi menganalisis permasalahan ketenagakerjaan di Indonesia mengalamai peningkatan. Hal ini berdasarkan hasil analisis yang dilakukan, diperoleh ketuntasan klasikal yaitu 53,33 persen meningkat menjadi 86,67 persen.
\end{abstract}

Kata Kunci: Pembelajaran Kooperatif; STAD; Penelitian Tindakan Kelas

\section{PENDAHULUAN}

Pendidikan merupakan salah satu keharusan dalam kebutuhan yang sangat penting bagi setiap individu, didalam pendidikan proses belajar mengajar dan proses pembelajaran merupakan inti pendidikan yang didalamnya melibatkan pendidik sebagai pengajar dan peserta didik. Disini terjadi interaksi antara pendidik dengan peserta didik lainnya. Melalui proses belajar ini akan tercapai tujuan pendidikan yaitu terjadi perubahan tingkah laku dan tercapainya hasil pembelajaran yang optimal. Disini pendidik berperan sangat penting dalam proses belajar mengajar.

Sejalan dengan apa yang digariskan dalam Undang-Undang No. 20 tahun 2003 dalam Pidarta (2004:6) tentang Sistem Pendidikan Nasional dikemukakan tujuan pendidikan nasional bahwa: Pendidikan nasional berfungsi mengembangkan kemampuan watak serta peradaban bangsa yang bermartabat dalam rangka mencerdaskan kehidupan bangsa bertujuan untuk berkembangnya potensi peserta didik agar menjadi manusia yang beriman dan bertaqwa kepada Tuhan Yang Maha Esa, sehat, berilmu, cakap, kreatif, mendiri dan menjadi warga Negara yang demokratif serta bertanggung jawab.

Pandangan umum yang masih dianut pendidik dalam proses belajar mengajar sampai sekarang ialah bahwa dalam proses belajar mengajar, pengetahuan mentransfer dari pendidik ke peserta didik. Pola pembelajaran ini menyebabkan aktivitas peserta didik dalam proses belajar pasif sehingga proses pembelajaran tidak merangsang peserta didik untuk kreatif dan tidak memiliki kemampuan kerjasama dalam kelompok. 
Nelly, Penerapan Model Pembelajaran...| 16

Fenomena kegiatan pendidikan masih jauh dari yang diharapkan, maka untuk menciptakan pendidikan yang baik, sudah saatnya pendidik harus menguasai model pembelajaran yang dapat mengembangkan keterampilan berpikir peserta didik karena peran seorang pendidik sangat penting dalam meningkatkan kompetensi peserta didik. Oleh karena itu, pendidik harus memikirkan dan membuat perencanaan secara skematis dalam pengajaran yang dilaksanakannya untuk meningkatkan kesempatan belajar bagi peserta didik dan memperbaiki kualitas mengajar, tugas seorang pendidik tidak hanya sekedar mengajar (teaching) tetapi lebih ditekankan pada pembelajaran yang dikembangkan oleh pendidik masih berpusat pada pendidik sebagai penyimpan materi. Kecendrungan pendidik otoriter dan instruktif menjadi komunikasi satu arah, disini pendidik yang berperan aktif sementara peserta didik pasif hanya menerima materi pelajaran yang disampaikan oleh pendidik, ini berarti pendidik kurang memberi peluang dan kebebasan kepada peserta didik untuk mengungkapkan pendapatnya sehingga peserta didik menjadi pasif dan situasi ini bertentangan dengan peserta didik belajar aktif.

Permasalahan seperti di atas terjadi pula di SMA Negeri 10 Bulukumba. Berdasarkan hasil observasi awal yang dilakukan pada tanggal 8 Maret 2018, diketahui bahwa peserta didik kelas XI masih cenderung pasif dalam proses pembelajaran. Interaksi aktif baik antara peserta didik dengan peserta didik, maupun antara peserta didik dengan pendidik juga masih tergolong kurang. Peserta didik lebih banyak melakukan aktivitas mencatat dan mendengarkan. Aktivitas lain seperti bertanya atau pun berpendapat dan bertukar pikiran masih sangat kurang, khususnya dalam mengikuti pembelajaran mata pelajaran Pendidikan Kewarganegaraan.

Salah satu alternatif untuk mengatasi masalah yang ada yaitu berupa penerapan model pembelajaran yang lebih mengutamakan keaktifan peserta didik dan memberi kesempatan peserta didik untuk mengembangkan potensinya secara maksimal. Model pembelajaran yang dimaksud adalah model pembelajaran kooperatif. Model pembelajaran kooperatif sangat cocok diterapkan pada pembelajaran Ekonomi karena dalam mempelajari Ekonomi tidak cukup dengan hanya mengetahui dan menghafal konsep-konsep Ekonomi tetapi juga dibutuhkan suatu pemahaman serta kemampuan menyelesaikan persoalan Ekonomi dengan baik dan benar.

Atas dasar pertimbangan itulah maka peneliti dapat menarik kesimpulan sementara bahwa pembelajaran yang dilakukan selama ini belum efektif. Salah satu kendala utamanya adalah dalam proses belajar mengajar antusias peserta didik untuk belajar sangat kurang, peserta didik lebih cenderung menerima apa saja yang disampaikan oleh pendidik, diam dan enggan mengemukakan pertanyaan maupun pendapat. Hal ini dikarenakan pembelajaran yang dilakukan oleh pendidik cenderung menggunakan metode pembelajaran konvensional, monoton pada metode ceramah saja sehingga peserta didik kurang semangat dalam proses pembelajaran tidak ada dinamika, inovasi, kreativitas dan peserta didik belum dilibatkan secara aktif sehingga pendidik sulit untuk mengembangkan dan meningkatkan kualitas pembelajaran. Hal ini menyebabkan kurang semangat dan kurang aktifnya peserta didik dalam mengikuti Ekonomi, sehingga menimbulkan kesulitan dalam memahami materi pelajaran Ekonomi Oleh karena itu, perlu adanya solusi agar hasil belajar peserta didik dapat meningkat.

Pada model pembelajaran kooperatif terdapat berbagai tipe, salah satu diantaranya tipe STAD (Student Teams Achivement Division). Tipe STAD ini dapat membantu siswa memahami konsep-konsep Ekonomi yang sulit, serta menumbuhkan kemampuan kerjasama, berfikir kreatif, dan mengembangkan sikap sosial peserta didik, pembelajaran kooperatif memiliki dampak yang positif terhadap siswa yang rendah belajarnya...Berdasarkan uraian diatas, peneliti tertarik untuk melakukan penelitian yang berjudul "Penerapan Model Pembelajaran Kooperatif tipe STAD (Student Teams Achievement Division) dalam Meningkatkan Hasil Belajar Ekonomi di Kelas XI SMA Negeri 10 Bulukumba".

Berdasarkan uraian tersebut, maka tujuan yang ingin dicapai dari penelitian ini adalah untuk mengetahui peningkatan hasil belajar ekonomi siswa dengan menggunakan Model Pembelajaran Kooperatif tipe STAD (Student 
Teams Achievement Division) pada kelas XI SMA Negeri 10 Bulukumba.

Beberapa teori yang dijadikan sebagai rujukan dalam penelitian ini, antara lain menurut Yamin (2012:96) menyatakan bahwa "belajar merupakan proses memperoleh kecakapan, keterampilan dan sikap". Dan Menurut Haling (2007:2) menyatakan bahwa "belajar adalah kegiatan psikofisik menuju perkembangan manusia seutuhnya". Sedangkan menurut Skinner dalam Dimyanti (2009:9) berpendapat bahwa "belajar adalah suatu perilaku. Pada saat orang belajar, maka responnya menjadi lebih baik. Sebaliknya, bila dia tidak belajar maka responnya menurun".

Sedangkan Menurut Biggs dalam Syah (2006:25) mendefenisikan belajar dalam tiga macam rumusan, yaitu: Rumusan kuantitatif, institusional, dan kualitatif. Rumusan kuantitatif mengartikan belajar sebagai kegiatan pengisian atau pengembangan kemampuan kognitif dengan fakta sebanyak-banyaknya. Secara institusional maksudnya, belajar dipandang sebagai proses validasi terhadap penguasaan siswa atas materi yang telah ia pelajari. Dalam rumusan kualitatif, difokuskan pada tercapainya daya pikir dan tindakan yang berkualitas untuk memecahkan masalah-masalah yang kini dihadapi siswa.

Belajar merupakan suatu proses perubahan sikap dan perilaku yang berdasarkan pengetahuan dan pengalaman. Pendapat tersebut di dukung oleh penjelasan Slameto (2011 :2) bahwa: Belajar adalah suatu proses usaha yang di lakukan seseorang untuk memeperoleh suatu perubahan tingkah laku yang baru secara keseluruhan sebagai hasil dari pengalamannya sendiri dalam berinteraksi dengan lingkungannya. Menurut Hilgar dalam Sanjaya (2008:229) menyatakan bahwa: Belajar adalah proses perubahan melalui kegiatan atau prosedur latihan baik dalam latihan di dalam laboratorium maupun dalam lingkungan alamiah. Kegiatan belajar memiliki tiga ciri, yaitu:

a. Belajar adalah perubahan tingkah laku.

b. Perubahan terjadi karena latihan dan pengalaman, bukan karena pertumbuhan.

c. Perubahan tersebut harus bersifat permanen dan tetap ada dalam waktu yang cukup lama.
Dari uraian tetang pengertian belajar maka dapat disimpulkan bahwa belajar adalah suatu proses perubahan tingkah laku yang melibatkan jiwa dan raga sehingga dapat menghasilkan perubahan dalam pengetahuan, pemahaman, pengalaman, sikap dan nilai yang dilakukan oleh seseorang melalui latihan dan pengalaman dan berinterasksi dengan lingkungannya yang selanjutnya akan disebut dengan hasil belajar

Kegiatan belajar mengajar dikatakan efisien jika hasil belajar yang diinginkan dapat dicapai dengan usaha yang sekecil mungkin. Perwujudan perilaku belajar biasanya dapat dilihat dari adanya perubahan-perubahan kebiasaan, keterampilan, dan pengetahuan, sikap dan kemampuan yang biasanya disebut sebagai hasil belajar. Belajar dan mengajar sebagai aktifitas utama di sekolah meliputi 3 unsur yaitu: tujuan pengajaran, pengalaman belajar mengajar dan hasil belajar. Hasil belajar adalah hasil yang dicapai siswa setelah mengalami proses belajar dalam waktu tertentu untuk mencapai tujuan yang ditetapkan.

\section{METODE}

Jenis penelitian ini adalah penelitian tindakan kelas (PTK). Penelitian tindakan kelas merupakan suatu jenis penelitian yang dilakukan oleh pendidik untuk memecahkan permasalahan dalam kelas. Penelitian ini bertujuan untuk memberikan gambaran tentang peningkatanpeningkatan hasil belajar peserta didik melalui penerapan model pembelajaran kooperatif tipe STAD

Subjek Penelitian Penelitian ini adalah siswa kelas XI di SMA Negeri 10 Bulukumba. Prosedur penelitian tindakan kelas ini direncanakan terdiri dari dua siklus. Tiap-tiap siklus dilaksanakan sesuai dengan perubahan yang akan dicapai, seperti yang telah didesain dalam faktor-faktor yang diselidiki.

Menurut Lewin dalam Kusuma (2011:27), menjelaskan bahwa dalam pelaksanaan tindakan pada tiap siklus mencakup 4 tahapan, yaitu: perencanaan, pelaksanaan tindakan, pelaksanaan tindakan, observasi, dan refleksi. Tahapan siklus yang dimaksud tersebut dapat juga kita lihat pada: 
Nelly, Penerapan Model Pembelajaran...| 18

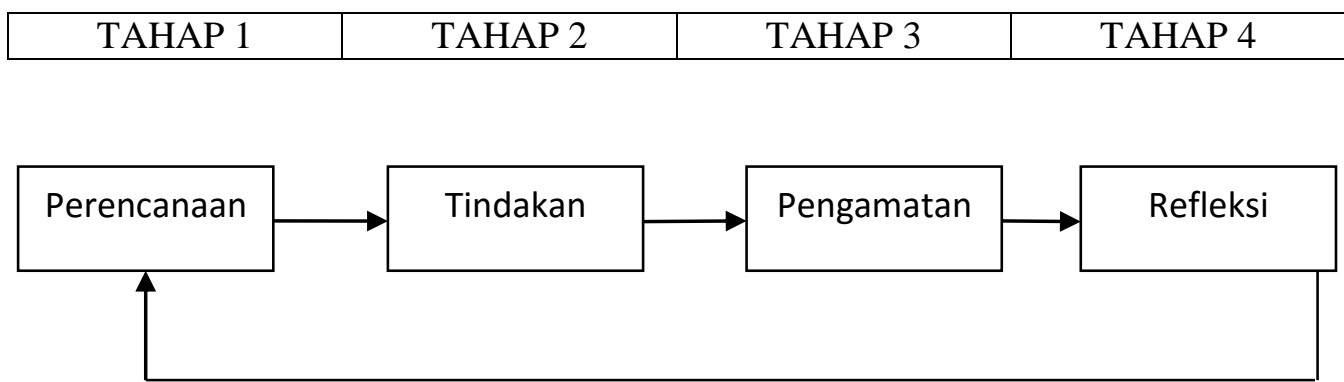

Sumber: Model Kurt Lewin dalam Kusuma (2011 :27)

Gambar 2.2. Tahapan Siklus Model Kurt Lewin

Sumber data dalam penelitian ini adalah bersumber dari pendidik dan peserta didik sedangkan jenis data yang akan diperoleh adalah data kuantitatif dan kualitatif. Dimana data kuantitatif diperoleh dari hasil belajar peserta didik dan data kualitatif diperoleh dari data hasil belajar peserta didik dan data kualitatif diperoleh dari lembar observasi. Adapun teknik pengambilan data dalam penelitian ini adalah :Teknik observasi, Teknik tes, Teknik dokumentasi,.

Teknik analisis data dalam penelitian ini dilakukan selama dan sesudah pengumpulan data. Analisis data dilakukan dengan mengelompokkan hasil perolehan data dari guru dan siswa. Teknik analisis data yang digunakan adalah teknik analisis data deskriptif kualitatif. Analisis data deskriptif digunakan untuk menghitung nilai ratarata dan persentase hasil belajar. Menurut Sudjono (2011:43) mencari presentase (\%) nilai rata-rata adalah :

$$
\mathrm{P}=\frac{f}{N} \quad x X I 0 \%
$$

\section{HASIL DAN PEMBAHASAN}

Penelitian tindakan kelas ini terdiri dari dua siklus. Penelitian ini berakhir setelah pelaksanaan siklus II yang telah mencapai indicator keberhasilan pembelajaran yang telah ditetapkan. Salah satu model pembelajaran yang melibatkan peran Peserta didik secara aktif adalah pembelajaran kooperatif tipe $S T A D$.

Berdasarkan evaluasi hasil belajar peserta didik pada pelaksanaan pembelajaran dengan pembelajaran kooperatif tipe STAD. Ditemukan bahwa pada dasarnya pembelajaran ini memiliki potensi yang cukup baik untuk meningkatkan pemahaman peserta didik terhadap mata pelajaran ekonomi. Hal ini ditunjukkan oleh rata-rata hasil tes peserta didik yang dilaksanakan di akhir pembelajaran pada setiap siklus mengalami peningkatan cukup signifikan. Pada siklus I, diperoleh skor tertinggi 3,20 dan skor terendah 1,58, rata-rata hasil belajar sebesar 2,55, dan berdasarkan tabel distribusi frekuensi diperoleh hasil bahwa sebanyak 52,94 persen (18 Peserta didik) berada pada kategori baik, 23,53 persen (8 Peserta didik) berada pada kategori Cukup, 20,59 persen (7 Peserta didik) berada pada kategori kurang, dan 2,94 persen (1 Peserta didik) berada pada kategori sangat kurang

Adapun ketuntasan belajar Peserta didik secara klasikal baru mencapai 52,94 persen (18 Peserta didik). Hal ini memberikan indikator bahwa hasil belajar Peserta didik sebelum pelaksanaan tindakan meningkat setelah pelaksanaan tindakan, tetapi belum mencapai indikator keberhasilan pembelajaran yang diharapkan yaitu ketuntasan individu 2,66 (sesuai dengan KKM) dan ketuntasan secara klasikal minimal 80 persen dari jumlah keseluruhan Peserta didik dalam kelas yang mencapai ketuntasan, sehingga perlu dilaksanakan siklus II. Hasil belajar ekonomi Peserta didik kelas XI SMA Negeri 10 Bulukumba setelah dilakukan tindakan pembelajaran STAD pada siklus II. Diperoleh data untuk nilai tertinggi yaitu 3,69 dan nilai terendah adalah 2,41 , serta rata-rata hasil belajarnya adalah 3,04 persen. Berdasarkan table distribusi frekuensi perolehan hasil belajar Peserta didik melalui model pembelajaran $S T A D$, yaitu 5,88 persen (2 Peserta didik) berada pada kategori sangat baik, 82,36 persen (28 Peserta 
Nelly, Penerapan Model Pembelajaran...| 19

didik) berada pada kategori baik, 11,76 persen (4 Peserta didik) berada pada kategori cukup, 0,00 persen (tidak ada Peserta Didik) berada pada kategori kurang, dan 0,00 (tidak ada Peserta didik) berada pada kategori sangat kurang.

\section{SIMPULAN DAN SARAN}

Berdasarkan rumusan masalah, hasil penelitian dan pembahasan penelitian yang berlangsung selama dua siklus, maka secara umum dapat disimpulkan bahwa hasil belajar ekonomi pada standar kempetensi menganalisis permasalahan ketenagakerjaan di Indonesia dapat meningkat melalui model pembelajaran kooperatif tipe $S T A D$ pada peserta didik kelas XI di SMA Negeri 10 Bulukumba. Adapun respon peserta didik dalam proses pembelajaran ekonomi terhadap model pembelajaran kooperatif tipe $S T A D$, termasuk dalam kategori sangat tinggi.

Dalam kegiatan belajar mengajar Pendidik diharapkan menjadikan model pembelajaran kooperatif tipe $S T A D$ sebagai suatu alternatif dalam pembelajaran ekonomi untuk meningkatkan hasil belajar peserta didik.

\section{DAFTAR RUJUKAN}

Agustan. 2012. Penerapan Model pembelajaran Kooperatif tipe STAD dalam Meningkatkan Hasil Belajar Siswa pada Mata Pelajaran Kewirausahaan di Kelas XI Pemasaran 3 SMK Negeri 1 Makassar. Makassar. FE UNM.

Akbar, Laode. 2014. Peningkatan Kompetensi Peserta Didik Tentang Bank Sentral Dan Otoritas Jasa Keuangan Melalui Model Pembelajaran Kooperatif Tipe Students Team Achievement (STAD) Pada Mata Pelajaran Ekonomi di Kelas XI Sosial 1 SMA Negeri 2 Watampone. Skripsi: Fakultas Ekonomi Universitas Negeri Makassar

Arikunto, Suharsimi. 2011. Penelitian Tindakan Kelas. Jakarta: Bumi Aksara.

Chaeriyah Siti. 2011 . Penerapan Model Pembelajaran Kooperatif Tipe Student Teams-Achievement Divisions (STAD) Untuk Meningkatkan Kemampuan Pemecahan Masalah Matematika Peserta didik Kelas Vii D Smp Negeri 2 Depok Pada Materi Bangun Segi Empat.
Skripsi: Fakultas Matematika Dan Ilmu Pengetahuan Alam UNY

Daryanto, 2011. Penelitian Tindakan Kelas Dan Penelitian Tindakan Sekolah. Yogyakarta: Gava Media.

Depdikbud. 1989. Garis Garis Besar Program Pembelajaran. Jakarta: Depdikbud.

Depdiknas. http:// nanunalmufarah. blogspot. com/2012/11 /karakteristik-bidang-studiekonomi-unla.html (Diakses Tanggal 02 Maret 2014)

Dewiatmini Pramita. 2011 . Upaya Meningkatkan Pemahaman Konsep Matematika Pada Pokok Bahasan Himpunan Peserta didik Kelas Vii A Smp Negeri 14 Yogyakarta Dengan Penerapanmodel Pembelajaran Kooperatif Tipe Student Teams Achievement Divisions (stad).Skripsi: Fakultas Matematika Dan Ilmu Pengetahuan AlamUNY

Dimyanti dan Mudjiono. 2009. Belajar dan Pembelajaran. Jakarta: Rineka Cipta

Haling, Abdul. 2007. Belajar dan Pembelajaran. Makassar: Badan Penerbit UNM Makassar.

Hardiyanti Isti. 2011, Upaya Meningkatkan Pemahaman Konsep Matematika Melalui Pendekatan Problem Posing Dengan Pembelajaran Kooperatif Tipe Stad Pada Peserta Didik Kelas Bilingual VIII c SMP $N 1$ Wonosari. Skripsi: Fakultas Matematika Dan Ilmu Pengetahuan AlamUNY

Isjoni. 20XI . Cooperatif Learning Efektifitas Pembelajaran Kelompok. Bandung: Alfabeta.

Kamdi, 2009. Siklus belajar, Pembelajaran Kooperatif dan Media Pendidikan Dalam pemebelajaran Fisika. www.wikipedia.org.com,diakses tanggal 11 Maret 2014

Kusuma, Wijaya, dan Dwitagama. 2011. Mengenal Penelitian Tindakan Kelas. Jakarta: PT. Indeks.

Lie, Anita. 2007. Cooperative Learning. Jakarta: Grasindo.

Mappasoro. 2001. Strategi Pembelajaran. Makassar: FIP-UNM

Pidarta, Made. 2004. Manajemen Pendidikan Indonesia. Jakarta: PT. Rineka Cipta. 
Rusman. 2011. Model pembelajaran kooperatif. Jakarta: PT Raja Grahafindo Persada.

Slavin, Robert. 2009. Cooperative Learning (Teori, Riset dan Praktik). Cetakan keIII. Bandung: Nusa Media.

Sanjaya. Wina. 2008. Penelitian Tindakan Kelas. Bandung: Kencana.

Slameto. 20XI . Evaluasi Pendidikan. Jakarta: Bina Aksara

Sudjana, Nana. 2005. Penilaian Hasil Proses Belajar Mengajar. Bandung: Remaja Rosdakarya.

Sudjono, Anas. 2011. Pengantar Evaluasi Pendidikan. Jakarta: Rajawali Pers.

Suprijono, Agus. 2009. Kooperatif Learning, Teori dan Aplikasi PAIKEM. Yogyakarta: Pustaka Pelajar

Syah, Muhibbin. 2006. Psikologi Pendidikan, suatu pendekatan. Bandung: PT.Remaja Rosdakarya

Taniredja, Takiran dkk. 2012. Model-Model Pembelajaran Inovatif. Bandung: Alfabeta

Wirnasari. 2012. Peningkatan Kompetensi Mengelola Konflik melalui Model Pembelajaran Kooperatif Tipe STAD Mata Pelajaran Kewirausahaan bagi Siswa Kelas XI Pemasaran 1 SMK Negeri 1 Makassar. Makassar. FE UNM.

Yamin, Martinis. 2012. Strategi Pembelajaran Berbasis Kompetensi. Ciputat. Referensi 